\title{
Models of New Femininity and Masculinity in Soviet Russia in the 1920s
}

\author{
By Marina L. Levitina
}

Spring 2013 Issue of KINEMA

\section{STARS OF EARLY AMERICAN CINEMA AS MODELS OF NEW FEMININITY AND MASCULINITY IN SOVIET RUSSIA IN THE 1920S}

This paper explores some of the cinematic links that existed in the 1920s between Soviet Russia and its great "Other", America. It argues that in that decade, stars of silent American cinema, in particular Douglas Fairbanks Sr., Pearl White, and Mary Pickford offered the Soviet viewers, as well as critics and filmmakers, alternative models of new masculinity and femininity.

For Soviet Russia in the 1920s, America became a kind of measuring stick of success ${ }^{(1)}$ on the road toward the new, technologically advanced and efficient Soviet society. While the communist future was not yet attained, and the country was undergoing a process of massive transformation, the adjective "American" acquired a new meaning: it became a metaphor for excellence ${ }^{(2)}$ and led to the appearance and wide use of the discursive practice of Americanization, both in the sphere of technology and working methods, and especially among the avant-garde artists and intellectuals who were concerned with transforming the human nature of Soviet citizens.

In the early twentieth century, there existed a certain perception in the Russian popular imagination of model American qualities. Among them were energy, inventiveness, resourcefulness, efficiency, optimism, a drive for success, and the frontiersman's adventurous, pioneering spirit. After 1917, these traits were praised as new exemplary qualities that the citizens of the young Soviet state needed to acquire. In the Soviet press of the 1920s, a widely used trope "Russian Americans" signified Soviet citizens of a new kind. People described in this way were usually the newly efficient, dynamic, and technologically skilful workers, ${ }^{(3)}$ the 1920s' prototype of the "extraordinary men" of the Stalinist thirties.

The general image of a positive American set of qualities was reinforced among the wider Russian population in the 1910s and 1920s by the imported American films. Between 1922 and 1928, American imports comprised $43.7 \%$ of all films shown on Soviet screens. During this time period, the total imports consisted of 744 American films, 393 German and 188 French films; 388 Soviet features were produced during the same period. ${ }^{(4)}$ American films dominated Soviet screens, and Russian viewers soon fell in love with Pearl White, Douglas Fairbanks Sr., Mary Pickford, Charles Chaplin, William S. Hart, and a number of other American stars. ${ }^{(5)}$ Characters represented by most of these American actors were dynamic, optimistic, inventive, and efficient.

Russian fascination with American cinema pre-dated the Revolution. American films were first imported into Russia in 1915, and by 1916 they became Russia's main foreign import. ${ }^{(6)}$ Since that time, American adventure serials enjoyed great popularity among Russian audiences. Most of these serialized films were structured around an active female lead character, played by the "serial queens" Pearl White, Cleo Madison, Kathlyn Williams, Ruth Roland, and Helen Holmes. Pearl White gripped the imagination of Russian viewers more than any other "serial queen."(7)

Pearl White was one of the earliest of Hollywood celebrities, at the very beginning of the evolution of the star system. ${ }^{(8)}$ Her heroines in films such as The Perils of Pauline (1914), The Exploits of Elaine (1915), Hazards of Helen (1914), and House of Hate (1918) undertook thrilling adventures and possessed great physical strength, dexterity and courage. For American female audiences, adventure serial stars like Pearl White became models of strong modern femininity. ${ }^{(9)}$

While in America the majority of adventure serial fans were female ${ }^{(10)}$, in Russia these films attracted the audience of both genders. For the male, as well as the female members of the Russian audience, these films were the main alternative to the slow, static, and psychology-driven native films made in the Russian style. ${ }^{(11)}$ 
Among the audiences who flocked to see Pearl White films in the years immediately before and after the Revolution, were many of the future Soviet avant-garde filmmakers. In 1922, Lev Kuleshov, father of the Soviet montage school, highlighted the dynamism of American adventure serials, their "maximum amount of movement" and what he called the "primitive heroism" of their lead stars as the main reasons of their success in Russia. ${ }^{(12)}$ Leonid Trauberg wrote in his memoirs that around 1922 or earlier, he and Grigorii Kozintsev, along with their Moscow visitors Sergei Eisenstein and Sergei Yutkevich, gathered in St. Petersburg for a seven-hour-long viewing marathon of six episodes of The Iron Claw (1916, distributed in Russia as Maska, kotoraia smeetsia [The Mask that Laughs]), starring Pearl White. Trauberg comments, "[f]or a full five years Pearl White was our idol."(13)

Incorporation of dynamism, American editing devices, and positive, modern American character traits into the films created by Soviet directors in the 1920s and 1930s was a reflection of their personal admiration of the vitality of American cinema and the attractive traits of its athletic and optimistic heroes and heroines.

Cinema became an important tool in the Party's attempt to forge the new female Soviet identity and in propagandizing women's equality with men. Through cinema, new role models and examples of new personality traits for women could be introduced. Soviet critics and filmmakers had to make a conscious effort in order to create films that would offer female viewers a model of a modern woman that would correspond to the new ideals of Soviet femininity and its newly encouraged equality. Like in their own country, popular American films presented also Soviet female viewers, as well as critics and filmmakers, with a number of ready-made new models of modern femininity.

Soviet film critics of the 1920s called upon filmmakers to apply some of the American filmic models in constructing the cinematic image of a New Soviet Woman. As mentioned, one of these models was the daring female "serial queen" of early American adventure serials, in particular represented by Pearl White. In Russia, the athletic fitness of the "serial queens" was perceived as unusual in a woman. Strong and active female protagonists were perceived as possessing a certain degree of masculinity. The appeal of such heroines and the stunts they performed played a part in spreading the new ideal of "masculine" femininity across Russia.

This kind of film heroine, a "girl sportsman" who is "healthy, strong, beautiful, [...] able to do anything" and is "not afraid of any dangers"(14) was highly admired by Soviet film critics. (15)They encouraged filmmakers to create such heroines in new Soviet films. The term travesti ${ }^{(16)}$ was sometimes applied to female heroines with what were seen as male character traits. In a 1925 issue of a Soviet film magazine, a Soviet critic defined a travesti heroine as "a woman appearing as a man, [or] a woman with a masculine soul and character."(17)

The second part of this definition fitted perfectly the goals of the Bolshevik version of women's emancipation, with its emphasis on equality in joining the Soviet work force. The author of the article emphasized that early American adventure serials with active female protagonists focused on their "masculine traits of character", "masculine logic", and "masculine deeds". (18) Only American actresses were listed as examples of the travesti image. The critic went on to praise the fact that "in our revolutionary adventure films, in the portrayals of our heroine, the image of a woman-hero, a woman with a man's soul, character and deeds is already beginning to form." (19)

The most literal example of the influence of the "serial queen" Pearl White on Soviet heroine portrayals is Sofia Zhozeffi's portrayal of Duniasha in Ivan Perestiani's Civil War adventure film Savur-mogila (1926), a sequel to the film Little Red Devils (1923). At the beginning of this film, Duniasha and her brother Mishka are shown watching the Pearl White film House of Hate (1918) in a Soviet movie theatre. Shots of the evil guerilla leader Nestor Makhno escaping from the Bolsheviks and setting a building on fire, in "real life" outside of the film theatre, are intercut with shots of Pearl White and her male partner played by Antonio Moreno in House of Hate being projected on the screen, where a vicious fight takes place near a stormy sea, followed by shots of Duniasha and her brother Mishka watching the film intensely. An intertitle announces, "The birth of our own White and Moreno."(20)

The message of the filmmakers is clear: there is a parallel between life (the Civil War) and art (American adventure serials). In Savur-mogila, American cinema prepares the Soviet teenagers to act heroically when surrounded by the dangers of the Civil War, and turns Duniasha into a New Soviet Woman. In order to 
deal with new reality, the Russian teenagers have to acquire the skills and qualities of the athletic, brave and heroic American film stars. Duniasha, the New Soviet Woman, needs to "become" Pearl White. The sequence ends with an intertitle that announces, "The ones who entered [the cinema] were Duniasha and Mishka, but the ones who left were Pearl and Antonio." (21) Thus, the rest of the film is coloured by this suggestion of transformation of identity of the main protagonists in the image of American film stars.

Yuri Tsivian notes the likeness of the costumes worn by Sofiia Zhoseffi in Little Red Devils and Savur-mogila, and by Natalia Glan who played Miss Mend in Fedor Otsep's Mess Mend (1924), as well as the costume of Oktiabrina in Kozintsev and Trauberg's Pokhozhdeniia Oktiabriny (1924), to the costumes of Pearl White's and Helen Holmes' characters. ${ }^{(2)}$ However, the likeness was not limited to costumes, but was also manifested in character traits. Other early examples of strong, dynamic, and physically fit women in Soviet films of the 1920s appear most often in films dedicated to portrayals of contemporary Soviet reality. Such are the young, fit swimmer Mariia Ivanova in Komarov's comedy Kukla s millionami [The Doll with the Millions] (1928); the village girl Natasha who gallops on a horse to save her beloved aviator in Gardin's Chetyre I piat' [Four and Five] (1924), as well as Vera Popova's character in the film Kirpichiki [Little Bricks], noted by the critic Abramov in his article mentioned below.

Another ideal of the new femininity that was later applied in constructing the image of the new Soviet cinematic heroine was the one presented by Russia's favourite female American star of the 1920s, Mary Pickford. In her films, Pickford portrayed vivacious young girls who were optimistic and joyful, and often came from poor backgrounds but succeeded in transforming themselves and achieving success within Cinderella-like narratives. At least twelve of Pickford's films were imported and widely shown in Russia from 1923 until 1929, some remaining in circulation as late as 1932. ${ }^{(23)}$ In an article entitled "A Woman of the New Land", Soviet critic Abramov called for filmmakers to create the new Soviet cinematic heroine that would be "simple", "joyful", and would have a "healthy, sincere" laughter. ${ }^{(24)}$ The "victorious innocence", ${ }^{(25)}$ joyfulness and sweet simplicity of Pickford's star image were very similar to the "poignant simplicity" that Soviet critics in the 1920s wanted to see in the new Soviet cinematic heroines. ${ }^{(26)}$

Vera Kuznetsova has pointed out Soviet critics' cautious attitude to Pickford's popularity. ${ }^{(27)}$ However, while often negatively commenting upon Pickford's "sweet bourgeois" ideology, ${ }^{(28)}$ Soviet critics in the 1920s had to take into account the great admiration on behalf of the viewers for Pickford's talent. The Soviet public adored her unquestionably. The adoration of the Soviet fans was expressed in the multi-thousand attendance of the arrival of Pickford and Fairbanks to Moscow in July, 1926. ${ }^{(29)}$

A short story in a 1926 issue of the magazine Sovetskii ekran, published a few months before Pickford and Fairbanks' arrival, satirized such love on behalf of Soviet female fans. Its central character is a fictitious young Soviet girl, Klavdiia Kovaleva, who lives in a tiny one-room flat, works at a glass factory, and has one ideal, Mary Pickford, whose portrait she keeps "where others keep a lit candle or have portraits of leaders of the Revolution." (30) Having learnt of Pickford's planned arrival to Moscow, Klavdiia writes her a letter where she says, "I love you so much, I adore you. You are a genius of an actress, you are a bright lighthouse in the blind seas of the everyday reality." ${ }^{(31)}$ Klavdiia's character, who signs the letter as "a poor working girl", signifies numerous female Pickford fans in Soviet Russia and sheds light on their social status. The title of the story, "The Standard", suggests the normalcy of such admiration of Pickford among young working Soviet women.

Admiration of Soviet audiences for Pickford was matched by admiration for her husband, the actor Douglas Fairbanks Sr. Several of Fairbanks' early features were shown in Moscow prior to $1925^{(32)}$, but it was largely thanks to his four hits imported since 1925, The Thief of Baghdad (1924), The Mark of Zorro (1920), Robin Hood (1922), and Don Q, Son of Zorro (1925), that Fairbanks became exceptionally popular in Russia. By 1928, when asked by journalists what they liked about foreign films, Soviet children most often mentioned Douglas Fairbanks, whose courage they wanted to emulate. ${ }^{(33)}$ A 1929 children's survey showed that Fairbanks' films The Thief of Baghdad and The Mark of Zorro were their top two favourites. ${ }^{(34)}$

The footage shot of Fairbanks and Pickford during their arrival to Moscow in 1926 was used by Sergei Komarov in a popular comedy called The Kiss of Mary Pickford (released in 1927). The plot revolves around a Chaplinesque movie theatre usher Goga Palkin (Igor' Il'inskii), whose sweetheart Dusya (Anel' Sudakevich) is an admirer of Fairbanks and rejects Goga after watching The Mark of Zorro. Throughout the 
film, Goga goes through a number of identity changes, trying to look and act like Fairbanks (practicing his smile and his leaps), and submitting himself to a number of uncanny tests so as to become a famous cinema "stuntman."

By the end of the film and following a kiss from Mary Pickford, Goga becomes a local celebrity and wins Dusya's love. The film satirically portrays the lengths to which some Russian men were willing to go in order to resemble the ideal masculinity of Douglas Fairbanks, as well as reflecting Soviet women's admiration for both Fairbanks and Pickford.

One of Fairbanks' outstanding qualities was his physical fitness: throughout all of his films shown in Russia, he performed numerous stunts and athletic feats. In The Thief of Baghdad, Fairbanks' character Ahmed climbs high walls, steels food that is being cooked on a balcony two floors high, and easily leaps over the heads of numerous Baghdadi men in prayer. Fairbanks created an image of exemplary male physicality, sporting strong muscles, which were a prominent visual attribute as Fairbanks was naked above the waist throughout most of the film.

Even prior to the appearance of Fairbanks' films in Russia, Soviet film journals praised American cinema for its focus on "sportsmen" heroes and their plots centering on courage, dexterity, and resourcefulness. A 1923 issue of Kino juxtaposed the "man-sportsman" of American cinema to the "usual European actor-intellectual with weak muscles." The author of the article, Veronin, called for the new Soviet cinema to be based on the work of new actor-heroes, inspired by American cinema. ${ }^{(35)}$ With the appearance of the exceptionally fit, muscular Fairbanks on Soviet screens, it was natural for his star image to become a model for the Soviet viewers and film critics, and eventually for new Soviet film heroes. In 1925, another Soviet critic, Ter-Oganesov, suggested that Fairbanks was an example of a new "sportsman" hero, a daredevil who "does everything that a hero of his type should do, and does it amazingly!"(36) Another critic, Abramov, praised Fairbanks as the ideal hero of American cinema and pointed out the lack of such an ideal hero in Soviet cinema so far. ${ }^{(37)}$

In addition to physical fitness, Fairbanks' Ahmed, as well as his Zorro and Robin Hood, all share another set of qualities widely admired by the Soviet viewers and critics: optimism, joyfulness (zhizneradostnost') and sense of humour. Descriptions of Fairbanks in Soviet cinema periodicals of the time emphasize his ability to make the viewers laugh: "Humour is the ever-present part of his pictures. Laughter, healthy and good laughter, traverses all his films as a kind of a central line," writes Ter-Oganesov in Kino-zhurnal A.R.K. ${ }^{(38)}$

Optimism and joyfulness were character traits that, in the 1930s, came to be officially encouraged in filmic portrayals of the New Soviet Man. Such human traits were best highlighted in the genre of comedy. Comedy was one of the genres most favoured by Boris Shumyatsky, the head of Soyuzkino (the main organization overseeing cinema affairs in the 1930s) for the new Soviet "cinema for the millions."(39)

In America, Douglas Fairbanks was known not only as a film star, but also as the author of self-help books on personal achievement, preaching the Horatio Alger code of success. ${ }^{(40)}$ Fairbanks also frequently wrote for Boys' Life, the official Boy Scouts magazine. ${ }^{(41)}$ Paula Marantz Cohen posits that his advice on individual success, on keeping fit, on making a start and advancing, as well as his star image itself created a dynamic ideal available for imitation for anyone, regardless of their class, religion, or political affiliation. ${ }^{(42)}$

It is unclear whether Fairbanks' books were available in Soviet Russia. Furthermore, the notion of individual success and individuality in general may not have been emphasized in the artistic and official Bolshevik discourse of the 1920s (where individualism was meant to be supplanted by the higher spiritual quality of collectivism). However, any talk of forging the New Soviet Man was bound to involve the process of individual self-improvement. According to Brooks, in many press references to the new type of worker in the 1920s, the quality of individual motivation was indeed emphasized along with such qualities as energy and personal initiative. ${ }^{(43)}$

Between 1928 and 1931 all imported films were taken off Soviet screens amidst the new policies of the Cultural Revolution. ${ }^{(44)}$ However, the purge could not affect personal memory of millions of Russian viewers. It is reasonable to assume that children of the 1920s, who became the Soviet adults of the Stalinist 1930s and 1940s, never forgot their childhood role models, including Pearl White, Mary Pickford and Douglas Fairbanks. Neither did those filmmakers who went on to create Socialist Realist cinema of the 1930s with 
its positive heroes, and who were striving to make their films popular and entertaining. Soviet cinema of the 1930s saw a rise in the number of new heroes and heroines that were athletic, optimistic, and efficient. Films and stars that had left a strong impression, continued to have an effect on future filmic hero(ine) representation.

[Editor's note: This is the complete text of the above article. The text in the printed version of KINEMA is incomplete, due to a technical glitch.]

\section{Notes}

1. Alan M. Ball, Imagining America: Influence and Images in Twentieth-Century Russia (Lanham: Rowman and Littlefield Publishers, Inc., 2003), 32.

2. Jeffrey Brooks, "The Press and Its Message: Images of America in the 1920s and 1930s" in Sheila Fitzpatrick et al, ed., Russia in the Era of NEP: Explorations in Soviet Society and Culture (Bloomington and Indianapolis, Indiana University Press, 1991), 235.

3. Brooks, "The Press and Its Message", 241, 247.

4. Figure based on Kepley and Kepley, "Foreign Films on Soviet Screens", p. 431.

5. For information about other factors in the snowballing of positive ideas about America among the Russian people in the 1920s, see Jay Leyda, Kino: A History of the Russian and Soviet Film (London: George Allen and Unwin Ltd., 1960), 152. For an insightful discussion of Soviet critical reception of other American stars in the 1920s, see Vera Kuznetsova, "Amerikanskie zdevzy v strane bol'shevikov", Kinovedcheskie zapiski, 85 (2007):196-248.

6. Boris S. Likhachev, "Materialy k istorii kino v Rossii (1914-1916) [Materials for the history of cinema in Russia, 1914-1916]", in Iz istorii kino (Materialy i dokumenty) [Fragments of Film History (Materials and Documents)] vol. 3 (Moscow, 1960), 65, 86. Quoted in Tsivian "Between the Old and the New," 39.

7. Among the Pearl White films shown in Russia prior to and soon after 1917 were The Perils of Pauline (1914), distributed in Russia under the name "Pod gipnozom millionov [Under the Hypnosis of the Millions]"; The Exploits of Elaine (1915) in Russia as "Tainy Nyu-Yorka [Mysteries of New York]"; The Iron Claw (1916) in Russia as "Maska, kotoraia smeetsia [The Mask that Laughs]"; House of Hate (1918), in Russia as "Dom nenavisti [House of Hate]". See Tsivian, "Between the Old and the New," 61; Likhachev, "Materialy k istorii kino v Rossii," 66; Elena Kartseva, "Amerikanskie nemye fil'my v sovetskom prokate [ American Silent Films in Soviet Distribution]" in Kino i vremia [Cinema and Its Time], vol. 1 (Moscow, 1960): 213-325.

8. Shelley Stamp, "An Awful Struggle Between Love And Ambition: Serial Heroines, Serial Stars, And Their Female Fans," in The Silent Cinema Reader, ed. Lee Grieveson and Peter Kramer (London: Routledge, 2004), 217. Many of these early stars were female actresses in adventure serials.

9. Shelley Stamp, "An Awful Struggle Between Love And Ambition: Serial Heroines, Serial Stars, And Their Female Fans," in The Silent Cinema Reader, ed. Lee Grieveson and Peter Kramer (London: Routledge, 2004), 217. Many of these early stars were female actresses in adventure serials.

10. Ibid.

11. See Yuri Tsivian, "Early Russian Cinema: Some Observations," in Inside the Film Factory: New Approaches to Russian and Soviet Cinema, ed. by Richard Taylor and Ian Christie (London: Routledge, 1994), 7-30.

12. Kuleshov, "Americanism," 72-73.

13. Kinovedcheskie zapiski [Film Studies Annals], No. 16 (1992), 111. Quoted in Tsivian, "Between the Old and the New,"

14. K. Oganesov, Pirl' Uait (Moscow: Kinopechat', 1926), 6.

15. For more on the "masculine" femininity of other American female stars, such as Priscilla Dean, see 
Kuznetsova, "Amerikanskie zvezdy v strane bol'shevikov", p. 219.

16. The Oxford Dictionary defines "en travesty" as "dressed as a member of the opposite sex, especially for a theatrical role." The word originates from the French travestir, "dressed in disguise." See The Concise Oxford English Dictionary, Tenth Edition, ed. by Judy Pearsall (Oxford University Press, 2002), p. 476.

17. Iu.B., "Travesti", Sovietskii ekran, 8/18 (1925) [no page numeration].

18. Iu.B. "Travesti" [no page numeration].

19. Ibid.

20. Antonio Moreno acted alongside Pearl White in House of Hate. Savur-mogila suggests his widespread popularity in Soviet Russia; however, his popularity appears to have been limited. For example, Kuznetsova does not mention his name among the names of American film stars popular in Russia in the 1920s. See Vera Kuznetsova, 'Amerikanskie zvezdy v strane bol'shevikov', pp. 196-248. Mishka's identification with Moreno, alongside Duniasha's identification with Pearl White, was most likely a device that made it easier for the filmmakers to convey both the male and the female identification with American stars of adventure films.

21. The function of the word "contagion" (zaraza), added at the end of the intertitle, was to appease those Soviet critics who were arguing against 'bourgeois' films on Soviet screens. (See, for example, Denise Youngblood, Movies for the Masses: Popular Cinema and Soviet Society in the 1920s (Cambridge University Press, 1992), 61.) Nowhere in the film was there any reference to the influence of American film stars on Soviet teenagers being negative.

22. Tsivian, "Between the Old and the New", p. 43.

23. For the list of Mary Pickford's films in Soviet distribution, see Elena Kartseva, "Amerikanskie nemye fil'my v sovetskom prokate", in Kino i vremia, vol. 1 (Moscow, 1960), 213-325.

24. T. Abramov, "Zhenshchina novoi zemli", Sovetskii ekran, 34 (1926), 6.

25. Bulgakova, "The Hydra of the Soviet Cinema", 151.

26. See, for example, the above-mentioned article by Abramov, 'Zhenshchina novoi zemli', p. 6, where the author praised the female face that was "poignantly simple" and the ideal of the new heroine that was joyful and 'without hysterics'.

27. Kuznetsova, "Amerikanskie zvezdy v strane bol'shevikov", 200.

28. M. Bronnikov, Etiudy o tvorchestve Meri Pikford (Leningrad, 1927), 6; Meri Pikford: biograficheskii ocherk s poslesloviem i pod redaktsiei N.M. Iakovleva (Moscow, 1927), 15. Quoted in Kuznetsova, 'Amerikanskie zvezdy v strane bol'shevikov', 200.

29. For a vivid description of Pickford's and Fairbanks' arrival, see Vlad. Korolevich, "Dovol'no Meri Pikford", in Sovetskii ekran, 32 (1926), 13.

30. S. Gekht, "Standart", Sovetskii ekran, 28 (1926), 6.

31. Gekht, 6.

32. K. Ter-Oganesov, "Duglas Ferbenks," in Kinozhurnal ARK, 1 (January 1925): 33. Earlier Fairbanks features shown in Moscow included, in their Russian version titles, Avantiura Salso Espado [The Adventure of Salso Espado], Uroki smeha [Lessons of Laughter], and Kariera Kassiusa Li [Career of Cassius Lee] (American Aristocracy). Also, see "Inostrannye kino-aktery [Foreign Film Actors]" in Sovetskii ekran, No. 2(12) 1925: [no page numeration].

33. Brooks, "The Press and Its Message," 237.

34. Youngblood, Movies for the Masses, 52 .

35. Veronin, "Kriticheskie zametki. Po povodu tekushchego repertuara [Critical Notes. On the Current 
Repertoir]" in Kino, 1/5 (January 1923): 11.

36. K. Ter-Oganesov, "Duglas Ferbenks", Kino-zhurnal A.R.K., 1 (1925), 33.

37. Al. Abramov, Duglas Ferbenks (Moscow: Kinopechat', 1926), 5. The full first name of the author is not indicated.

38. K. Ter-Oganesov, "Duglas Ferbenks," in Kino-zhurnal A.R.K, 1 (January 1925): 33.

39. Richard Taylor, "Ideology as Mass Entertainment: Boris Shumyatsky and Soviet Cinema in the 1930s," in Inside the Film Factory, 208.

40. Quoted in Brooks, "The Press and Its Message," 237. Horatio Alger, a writer and author of "Strive and Succeed" philosophy, wrote stories based on the rags-to-riches formula in the second half of the $19^{\text {th }}$ century; "he preached that by honesty, cheerful perseverance, and hard work the poor but virtuous lad would have his just reward." Encyclopedia Britannica, www.britannica.com/EBchecked/topic/14993/Horatio-Alger, accessed May 19, 2009.

41. Robert Gottlieb, "The Silent Superstar," in New York Review of Books, vol. 56, no. 3 (February 26, 2009). The Soviet Pioneers organization for children was founded in 1922 and was based at least in part on the world scouting movement.

42. Cohen, Silent Film and the Triumph of the American Myth, 104.

43. Cohen, 241.

44. For more on the purge of imported and domestic films, see, for example, Ekaterina Khokhlova, "Forbidden Films of the 1930s", in Stalinism and Soviet Cinema, ed. by Richard Taylor and Derek Spring (London and New York: Routledge, 1993).

\section{References}

\section{Works Cited}

Abramov, Al. Duglas Ferbenks. Moscow: Kinopechat', 1926.

Abramov, T. "Zhenshchina novoi zemli." Sovetskii ekran, 34 (1926): 6.

Ball, Alan M. Imagining America: Influence and Images in Twentieth-Century Russia. Lanham: Rowman and Littlefield Publishers, Inc., 2003.

Bronnikov, M. Etiudy o tvorchestve Meri Pikford. Leningrad, 1927.

Brooks, Jeffrey. "The Press and Its Message: Images of America in the 1920s and 1930s." Russia in the Era of NEP: Explorations in Soviet Society and Culture. Ed. Sheila Fitzpatrick et al. Bloomington and Indianapolis: Indiana University Press, 1991.

Bulgakova, Oksana. "The Hydra of the Soviet Cinema: The Metamorphoses of the Soviet Film Heroine." Red Women on the Silver Screen: Soviet Women and Cinema from the Beginning to the End of the Communist Era. Lynne Attwood, ed. London: Pandora Press, 1993.

Cohen, Paula Marantz. Silent Film and the Triumph of the American Myth. Oxford: Oxford University Press, 2001.

Gekht, S. "Standart", Sovetskii ekran, 28 (1926): 6.

Gottlieb, Robert. "The Silent Superstar." New York Review of Books, vol. 56, no. 3 (February 26, 2009).

Hellebust, Rolf. Flesh to Metal: Soviet Literature and the Alchemy of Revolution. Ithaca and London: Cornell University Press, 2003.

Iu.B., "Travesti." Sovetskii ekran, 8/18 (1925) [no page numeration]. 
Kaganovsky, Lilya. How the Soviet Man Was Unmade: Cultural Fantasy and Male Subjectivity under Stalin. Pittsburgh: University of Pittsburgh Press, 2008.

Kartseva, Elena. "Amerikanskie nemye fil'my v sovetskom prokate [ American Silent Films in Soviet Distribution]." Kino i vremia [Cinema and Its Time]. Vol. 1. Moscow, 1960: 213-325.

Kepley, Jr., Vance and Betty Kepley, "Foreign Films on Soviet Screens, 1922-1931." Quarterly Review of Film Studies, 4.4 (Fall 1979): 429-442.

Khokhlova, Ekaterina. "Forbidden Films of the 1930s." Stalinism and Soviet Cinema. Richard Taylor and Derek Spring, eds. London and New York: Routledge, 1993.

Korolevich, Vlad. "Dovol'no Meri Pikford." Sovetskii ekran, 32 (1926): 13.

Kuleshov, Lev. "Americanism." The Film Factory: Russian and Soviet Cinema in Documents, 1896-1939. Richard Taylor and Ian Christie, eds. Cambridge: Harvard University Press, 1988: 72-73.

Kuznetsova, Vera. "Amerikanskie zdevzy v strane bol'shevikov." Kinovedcheskie zapiski, 85 (2007): 196-248.

Leyda, Jay. Kino: A History of the Russian and Soviet Film. London: George Allen and Unwin Ltd., 1960.

Likhachev, Boris S. "Materialy k istorii kino v Rossii (1914-1916) [Materials for the history of cinema in Russia, 1914-1916]." Iz istorii kino (Materialy $i$ dokumenty) [Fragments of Film History (Materials and Documents)]. Vol. 3. Moscow, 1960.

Meri Pikford: biograficheskii ocherk s poslesloviem i pod redaktsiei N.M. Iakovleva. Moscow, 1927.

Oganesov, K. Pirl' Uait. Moscow: Kinopechat', 1926.

Skulj, Jola. "Comparative Literature and Cultural Identity." CLCWeb: Comparative Literature and Culture 2.4 (2000). Web. 18 April 2009.

Stacey, Jackie. "Feminine Fascinations: Forms of Identification in Star-Audience Relations." The Film Studies Reader. Joanne Hollows et al, eds. London: Hodder Headline Group, 2000. 147-154.

Stamp, Shelley. "An Awful Struggle Between Love And Ambition: Serial Heroines, Serial Stars, And Their Female Fans." The Silent Cinema Reader. Lee Grieveson and Peter Kramer, eds. London: Routledge, 2004.

Taylor, Richard. "Ideology as Mass Entertainment: Boris Shumyatsky and Soviet Cinema in the 1930s." Inside the Film Factory: New Approaches to Russian and Soviet Cinema. Richard Taylor and Ian Christie, eds. London and New York: Routledge, 1991. 193-216.

Ter-Oganesov, T. "Duglas Ferbenks." Kinozhurnal ARK, 1 (January 1925): 33.

The Concise Oxford English Dictionary. Tenth Edition. Judy Pearsall, ed. Oxford University Press, 2002.

Tsivian, Yuri. "Between the Old and the New: Soviet Film Culture in 1918-1924." Griffithiana, 55/56 (1996): 15-63.

. "Early Russian Cinema: Some Observations." Inside the Film Factory: New Approaches to Russian and Soviet Cinema. Richard Taylor and Ian Christie, eds. London: Routledge, 1994.

Usenko, Oleg. "Zhiznennye idealy i normy povedeniia russkih v 'nemom' igrovom kino (1908-1919)." Istoriia strany, istoriia kino. S.S. Sekirinsky, ed. Moscow: Znak, 2004.

Veronin, "Kriticheskie zametki. Po povodu tekushchego repertuara [Critical Notes. On the Current Repertoir]." Kino, 1/5 (January 1923): 11.

Youngblood, Denise. Movies for the Masses: Popular Cinema and Soviet Society in the 1920s. Cambridge University Press, 1992. 


\section{Author Information}

Dr Marina Levitina teaches Russian Cinema and Russian Cultural Studies at the University of Dublin Trinity College, and Creative Arts/Engaged Filmmaking at NUI (Galway). Her research interests include early Soviet cinema and culture, the cinema of Andrei Tarkovsky, cinema and memory. She is also a documentary filmmaker. 